\title{
Laparoscopic removal of a large abdominal foreign body granuloma using single incision laparoscopic surgery (SILS) and extraction bag in a cheetah (Acinonyx jubatus)
}

\author{
Marthinus Jacobus Hartman, ${ }^{1}$ Robert Murco Kirberger, ${ }^{1}$ \\ Adrian Stephen Wolferstan Tordiffe, ${ }^{1,2}$ Sonja Boy, ${ }^{3}$ Johan Petrus Schoeman ${ }^{1}$
}

\begin{abstract}
${ }^{1}$ Companion Animal Clinical Studies, University of Pretoria, Pretoria, Gauteng, South Africa ${ }^{2}$ National Zoological Gardens of South Africa, Pretoria, Gauteng, South Africa ${ }^{3}$ School of Oral Health Sciences, University of Limpopo, Pretoria, Gauteng, South Africa
\end{abstract}

\section{Correspondence to} Dr Marthinus Jacobus Hartman,

marthinus.hartman@up.ac.za

\begin{abstract}
Acknowledgement We thank Karl Storz (South Africa and Namibia) for supplying and managing all the laparoscopic equipment and the instrumentation and Covidien for supplying the SILS port and LigaSure hand piece. We would also like to thank the staff and directors of the AfriCat foundation for the use of their facilities and support. Prof. Eric Monnet of Colorado State University for assisting with laparoscopic surgery and Mr. Simon Palmer for providing some photographic images.
\end{abstract}

\section{SUMMARY}

This case presents a thorn-induced abdominal foreign body granuloma that was removed with single incision laparoscopic surgery and an extraction bag. An 11-yearold female cheetah presented for routine laparoscopic ovariectomy. Abdominal palpation detected a midabdominal mass. Differential diagnoses were neoplasia and foreign body. Laparoscopic exploration of the peritoneal cavity revealed an omentalised mass, which was successfully removed with the aid of bipolar electrocoagulation. Microscopic investigation intraoperatively and postoperatively confirmed extensive foreign body-induced granulomatous inflammation. The foreign body was well encapsulated by fibrous tissue with no adjacent stricture formation. The patient made a complete recovery, and this is the first case report of a thorn-induced abdominal foreign body removed with minimally invasive surgery in a wild African carnivore.

\section{BACKGROUND}

Reports on gastrointestinal tract (GIT) foreign bodies (FB) in dogs are common and are typically associated with related clinical signs; conversely, reports in cats are rare and usually limited to linear FB. Various types of abdominal FB have been reported in dogs, which usually remain confined to the GIT lumen (Larson and Madsen 2010, Becker 2011, Creedy and Bates 2011, Battisti and others 2012, Allman and Pastori 2013, Nair and others 2013, Kassem and others 2014). GIT-related FBs are typically removed surgically (Kassem and others 2014) or less commonly endoscopically (Shin and others 2010, Baranidharan and others 2013). Moreover, after initial ingestion, GIT-related FB may penetrate through the muscular wall of GIT and migrate to their final location (Hunt and others 2004), where they may result in an extramural, omental pyogranulomatous (Papazoglou and others 2010, Nakata and others 2012) reaction or abscess (Spring 2011). A pyogenic granuloma, not caused by an FB, has also been reported in association with GIT in a dog (Nakata and others 2012). Once freed from GIT, the intra-abdominal FB may follow a migratory route, traverse vital structures (Kelly and others 2013) or create an enterocutaneous fistula (Brennan and others 2004, Wunderlin and others 2012). Intra-abdominal FB in animals have been described in strange locations. For example, plant material has been found in the bladder of a dog (Barrault and Vedrine 2013) and the spleen of a cat (Culp and Aronson 2008). Metallic FB have been removed from a dog's spleen (Mahajan and others 2012) and have caused intramural pyogranuloma with GIT obstruction (Papazoglou and others 2010). In cattle, FB penetration of the reticulum is well known (Braun 2009, Debosri and Sonal 2013, Smolec and others 2013) and sharp FB penetration has also been reported in buffaloes (Aref and Abdel-Hakiem 2013). Spiked wooden objects, for example, kebabs, ice-lolly sticks, wooden skewers, a toothpick and a satay stick, have been found to penetrate GIT in dogs (Hunt and others 2004, Stander and Kirberger 2011).

Iatrogenically induced FB such as textiloma or gossypiboma caused by retained surgical swabs (Deschamps and Roux 2009) is probably the most frequently reported coelomic cavity FB in dogs and is also of concern in human surgery (Yakasai and Abubakar 2011, Awowole and others 2014). In one case report, an abdominal swab migrated transmurally into the jejunum of a dog (Day and others 2012) and literature reports of retained surgical swabs or sponges resulting in abdominal fibrosarcoma exist (Haddad and others 2010; Rayner and others 2010). The ultrasonographic characteristics of textiloma and gossypiboma in dog have been well described (Choi and others 2011).

Obstructive GIT and abdominal FB are traditionally removed via celiotomy, but laparoscopic surgery is available as a less invasive surgical option. The concurrent use of extraction bags or pouches is aimed at reducing the size of the surgical incision and serves to avoid contamination or neoplastic seeding in the case of malignant neoplasia. To the author's knowledge, the use of an extraction bag for FB removal in a wild animal has not been reported previously.

\section{CASE PRESENTATION}

An 11-year-old cheetah, weighing $31.1 \mathrm{~kg}$ with a packed cell volume (PCV) of 31 per cent, presented for routine laparoscopic ovariectomy during a cheetah sterilisation project in Namibia. All captive cheetahs in Namibia are required by law to be permanently sterilised. The cheetah was immobilised via remote injection with a combination of $1.2 \mathrm{mg} / \mathrm{kg}$ zolazepam/tiletamine (Zoletil, Virbac RSA, 
FIG 1: Sagittal transabdominal ultrasound images of the thorn-induced granuloma. (a) The granuloma is seen between the measured callipers with the echogenic exudate caudal to the mass. (b) Image slightly more medially. Colour flow Doppler illustrates the vascularity of the mass
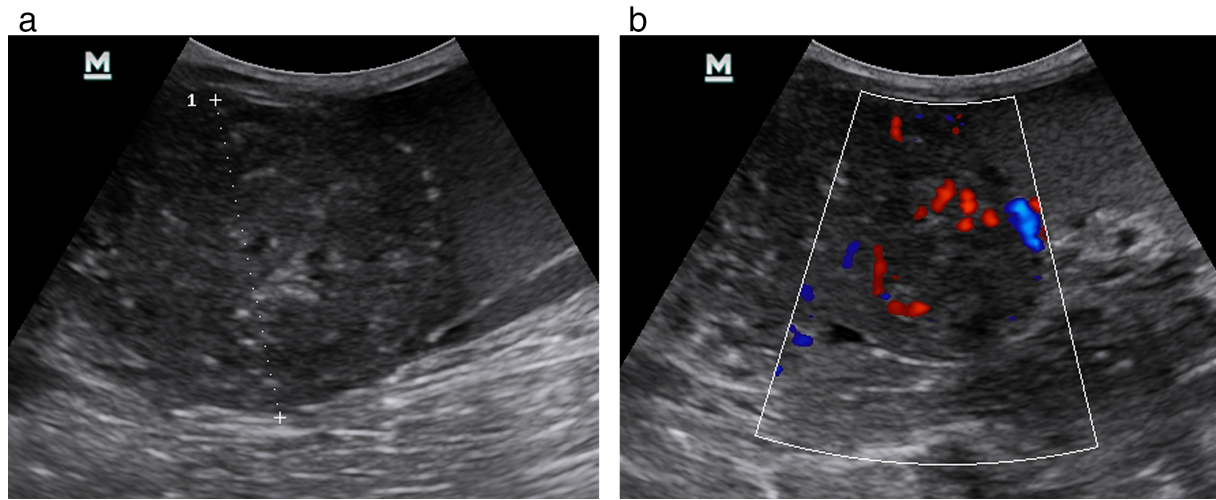

Centurion, South Africa) and $0.035 \mathrm{mg} / \mathrm{kg}$ medetomidine (Medetomidine $10 \mathrm{mg} / \mathrm{ml}$, Kyron Laboratories, Johannesburg, South Africa) and transported to the clinic where it was intubated and maintained under anaesthesia with isoflurane (Forane, Abbott Laboratories SA, Roodepoort, South Africa) in oxygen. An 18-gauge intravenous catheter (Jelco, Smiths Medical, Croydon, South Africa) was placed in the cephalic vein and lactated Ringer's (Sabax Ringer-Lactate, Adcock Ingram Critical Care, Johannesburg, South Africa) was administered intravenously at a rate of $10 \mathrm{ml} / \mathrm{kg} /$ hour. A single $6 \mathrm{mg}$ dose of meloxicam (Metacam $5 \mathrm{mg} / \mathrm{ml}$, Ingelheim Pharmaceuticals, Randburg, South Africa) was given 30 minutes before surgery.

\section{INVESTIGATIONS}

A mid-abdominal mass was palpated during clipping of the abdomen. Subsequently, abdominal ultrasonography found a round $6 \mathrm{~cm}$ diameter well-vascularised mass, not associated with any specific abdominal organ, in the mid right abdominal cavity (Fig 1). The mass had a fairly homogenous echo texture, which was isoechoic to the renal medulla with multiple small anechoic and hyperechoic areas throughout. Surrounding the mass, but mainly caudally, a moderate fairly echogenic, isoechoic to the spleen, abdominal effusion compatible with an exudate was present. Ultrasound-guided fluid aspiration revealed a cloudy and

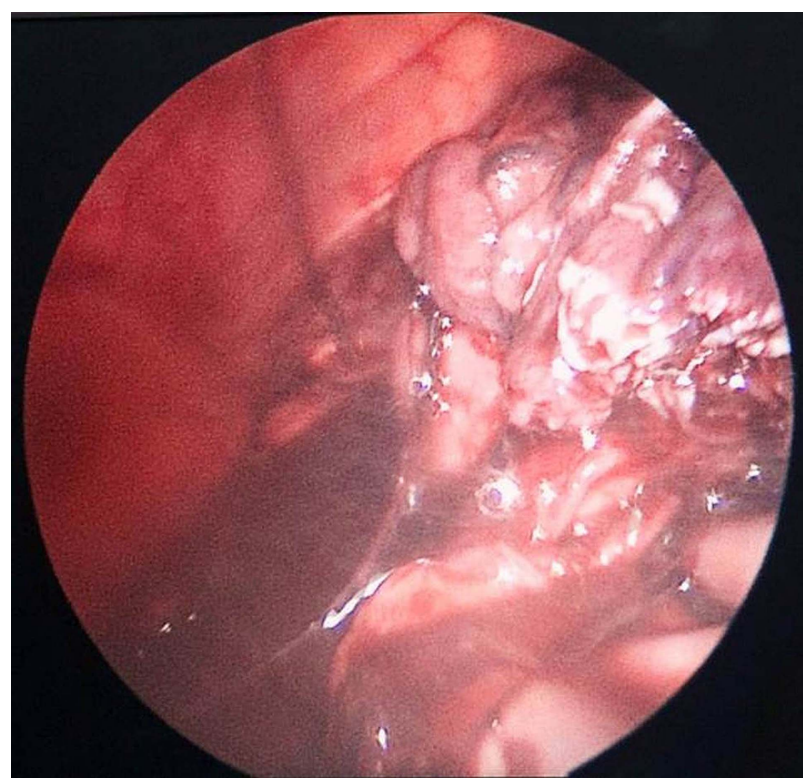

FIG 2: Ometalised granulomatous mass suspended by a Babcock forceps with some free blood in the peritoneal cavity turbid-appearing fluid, which on centrifuging had a sizeable cellular pellet. Microscopic examination of cytological smears prepared from the effusion demonstrated a majority of degenerate neutrophils, with approximately 20 per cent large mononuclear cells. The mononuclear cells resembled macrophages with vesicular cytoplasm indicative of phagocytosed content. Additional ultrasound-guided fine needle aspiration of the mass showed similar microscopic features with sheets of large cells, consistent with macrophages and active fibroblasts. Many of the neutrophils and macrophages contained phagocytosed rod-shaped bacteria.

\section{DIFFERENTIAL DIAGNOSIS}

Differential diagnoses considered before surgery were intraomental neoplasia or FB granuloma not associated with GIT.

\section{TREATMENT}

The patient proceeded to laparoscopy for ovariectomy and surgical removal of the mass. She was surgically prepared and draped and a single incision laparoscopic surgery port (SILS Port, Covidien, Mansfield, Massachusetts, USA) was placed immediately caudal to the umbilicus after local infusion with ropivacaine (Naropin, $7.5 \mathrm{mg} / \mathrm{ml}$, AstraZenaca Pharmaceuticals, Sunninghill, Johannesburg, South Africa). The mass embedded in omentum (Fig 2) was found in the region of the nephrosplenic ligament. The mass was secured with an atraumatic Babcock forceps and the highly vascularised omentum was coagulated and cut using a $10 \mathrm{~mm}$ Ligasure handpiece (Valleylab). Extensive coagulation was required to free the mass; however, no major intraoperative haemorrhage was experienced. After introduction of the extraction bag (volume: $800 \mathrm{ml}$ for use with

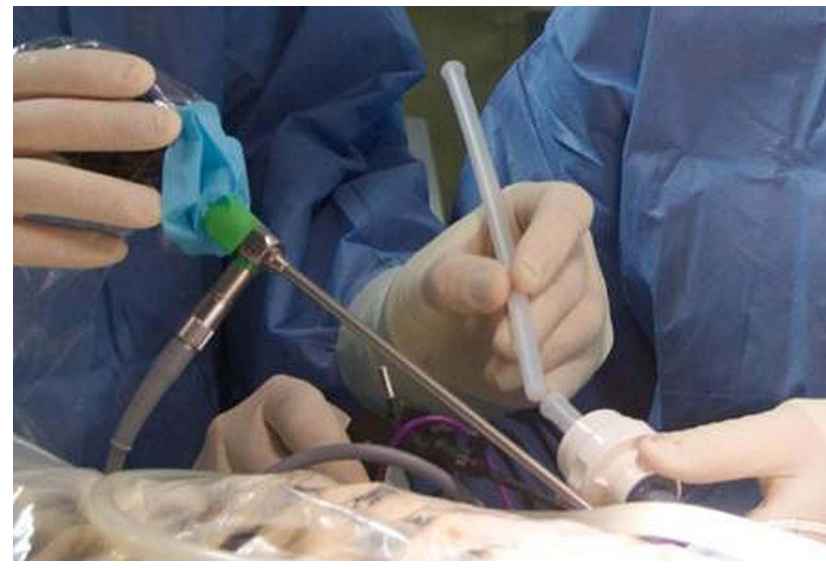

FIG 3: Introduction of an extraction bag via the 5-12 $\mathrm{mm}$ single incision laparoscopic surgery port 


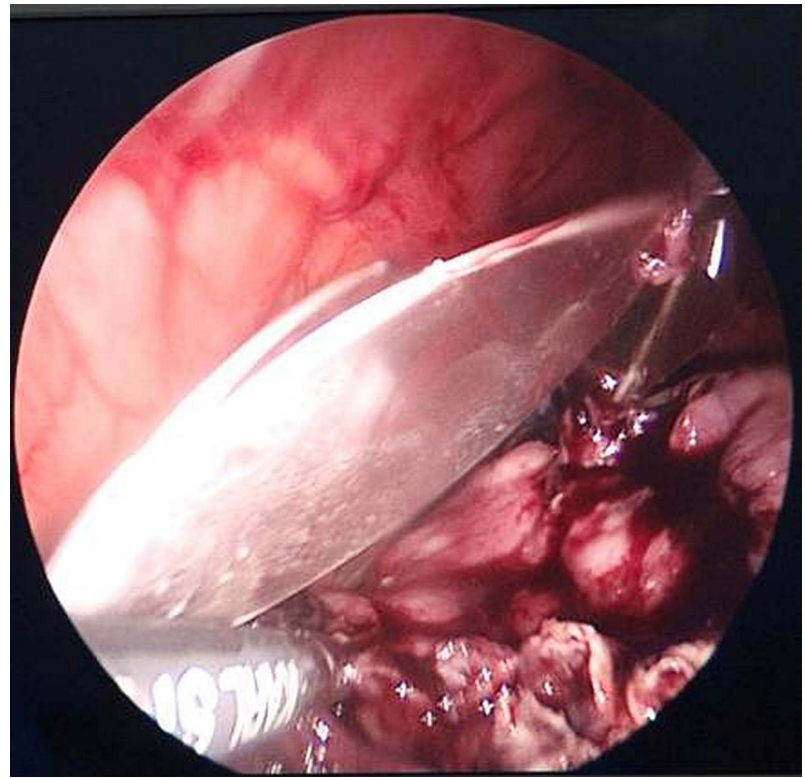

FIG 4: Deployment of the extraction bag inside the peritoneal cavity

$10 \mathrm{~mm}$ trocars, Medical Technical Promotion GMBH, GewerbePark, Neuhausen) through the 5-12 mm SILS port (Fig 3) and intra-abdominal deployment (Fig 4), the mass was placed into the bag with one forceps while holding the bag with another (Fig 5). The tip of the noose from the extraction bag was retrieved through the $5-12 \mathrm{~mm}$ port and removed together with the SILS port. The incision was enlarged to permit retrieval of the bag and its contents (video clip). The SILS port was then replaced and temporary crossed mattress sutures were placed to create a tight seal around the port. The abdomen was re-insufflated and the resection site was inspected for signs of haemorrhage. Ovariectomy was completed as described elsewhere (Hartman, under review) and the peritoneal cavity was lavaged with 31 of lukewarm Ringer's lactate solution. The SILS port was removed and the surgical site routinely closed.

The patient recovered uneventfully and was given a single $3.1 \mathrm{ml}(248 \mathrm{mg}$ ) subcutaneous dose of cefovecin (Convenia, Zoetis, Sandton, South Africa).

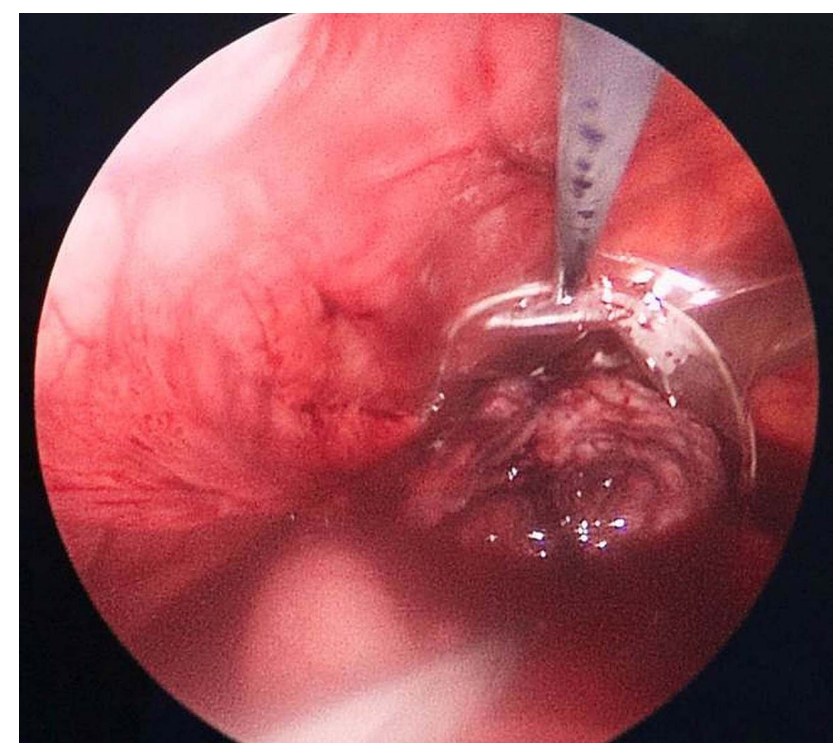

FIG 5: Resected mass is placed into the extraction bag

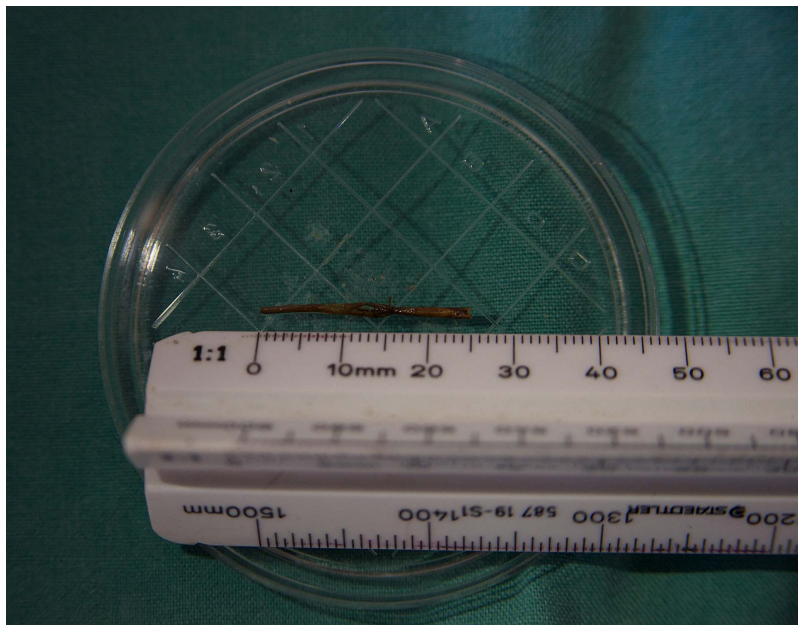

FIG 6: Thorn foreign body removed from the granuloma

\section{OUTCOME AND FOLLOW-UP}

Subsequent macroscopic examination of the excised mass revealed a firm yellow-white soft tissue mass. On serial incision through the specimen, a $25 \mathrm{~mm}$ thorn-like structure (Fig 6) resembling that of Dichrostachys cinerea (Sickle or Chinese lantern bush), a common thorn tree in Northern Namibia, coated with puss was found in the central aspect of the soft tissue mass (Fig 7). Histological examination of the mass exhibited cellular immature and hypocellular mature connective tissue with pockets of subacute inflammatory cell infiltrates distributed throughout the fibro-fatty tissue. Microabscess formation with sheets of neutrophils, large collections of foamy histiocytes and bacterial colonies were seen on all the evaluated sections (Fig 8). No cellular proliferation suggestive of neoplasia was present, which was all in keeping with a reactive inflammatory process. The possibility of an inflammatory myofibroblastic tumour/ inflammatory pseudotumor (neoplastic entity) was discarded due to the presence of the foreign material that was ostensibly responsible for the granulomatous mass.

\section{DISCUSSION}

This is the first report to describe the laparoscopic removal of an FB-induced granuloma from the abdomen of a cheetah. Granuloma formation in this species has not been well described. Similarly, reports on laparoscopic surgery in this

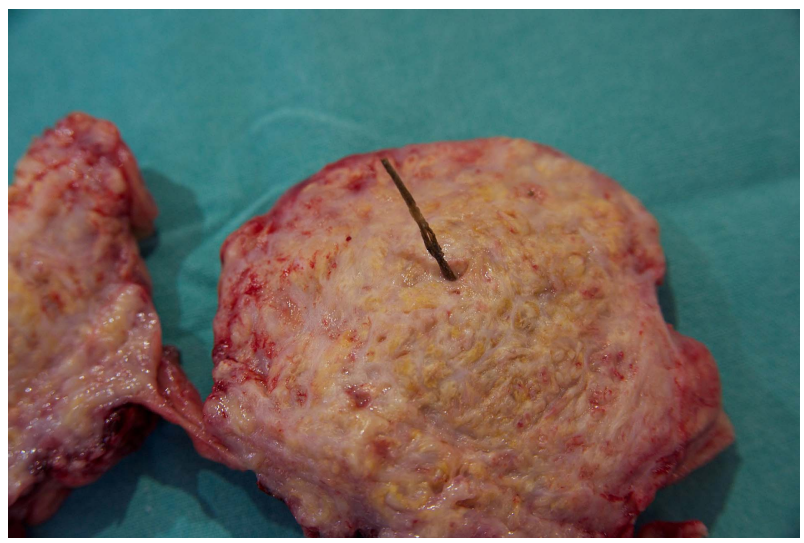

FIG 7: Incised granuloma revealing the foreign body 


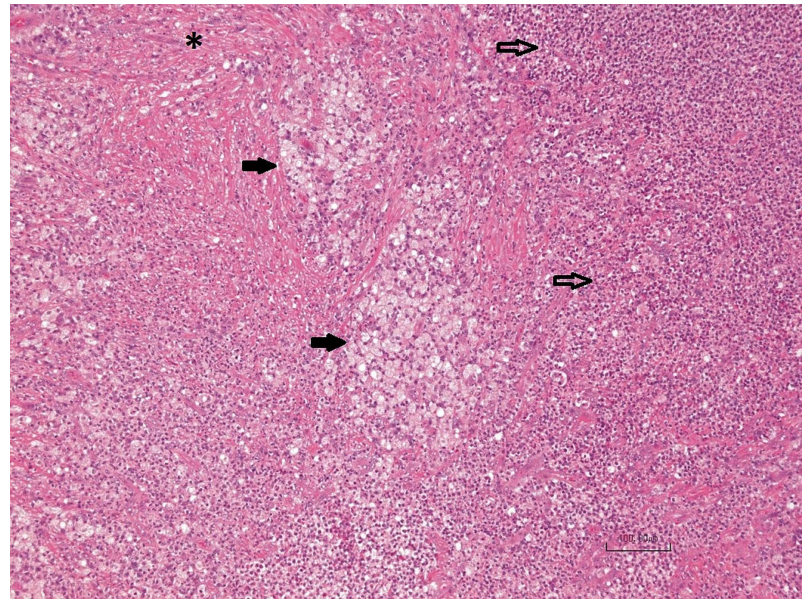

FIG 8: Microscopic image demonstrating clusters of foamy histiocytes (closed arrows) in a background of acute inflammation with puss (open arrows) and early fibrosis (asterisk) (scale bar: $100 \mu \mathrm{m}$ )

species are sparse, particularly those describing the laparoscopic excision of abdominal masses.

The cheetah is known for its strong cellular immune system and probably limited requirement for a humoral response to bacterial infection (Wachter 2014). In this cheetah, a wellencapsulated and omentalised FB was detected by ultrasound before surgery and confirmed by intraoperative cytology. The small amount of free peritoneal fluid was indicative of the marked extent to which this patient could encapsulate FB.

Standard straight laparoscopic instruments have been reported to create instrument cluttering when applied through a single access port (Manassero and others 2012, Runge and others 2012, Wilson and Monnet 2012, Runge and Mayhew 2013) and curved or articulated instruments have been suggested to improve ease of surgery (Runge and Mayhew 2013). However, this does require additional instrumentation and surgical skills. We experienced minimal surgical restraint as a result of instrument cluttering during this procedure. The use of extraction bags or pouches to remove abdominal structures has not been described in large cats. They have however been used for laparoscopic cryptorchidectomy (Spinella and others 2003), adrenalectomy (Naan and others 2013), nephrectomy (Kim and others 2013), cholecystectomy (Lee and others 2011) and splenectomy (Bakhtiari and others 2011) in dogs and ovariectomy in horses (Hanrath and Rodgerson 2002, Rodgerson and others 2002, Hoogmoed and Galuppo 2005, Bont and others 2010) and tigers (Emerson and others 2013) using three or four separate ports. The use of these bags or pouches has also not been described with SILS. Commonly with smaller ports, the surgical incision size has to be increased to allow retrieval of the bag and its contents. Depending on the structural content size, the $20 \mathrm{~mm}$ SILS incision might be large enough for retrieval compared with a $10 \mathrm{~mm}$ incision for individual ports; however, this has not been determined. Morcillators have been used during granulosa-theca cell tumours resection (Kummer and others 2010) and laparoscopic ovariectomy (Lund and others 2014) in mares. During this procedure, tissue is morcellated (minced) inside a bag or pouch and suctioned out to avoid enlargement of the incision site. Although its application has not been described in carnivores, the use of a morcellator could have been considered in our patient. However, the equipment was not available on site and would have destroyed the macroscopic structure of the mass, limiting the diagnostic value of the tissue.
In our case, the incision had to be enlarged in order to retrieve the bag and its content, which measured $6 \mathrm{~cm}$ in diameter on ultrasound. This did create the need to place temporary abdominal wall sutures to recreate a tight seal around the SILS port in order to complete ovariectomy. Performing ovariectomy before granuloma retrieval could have prevented this situation; conversely, removing the space-occupying lesion from the peritoneal cavity first did restore some normal visceral anatomy and made subsequent ovariectomy easier.

Entrance of the thorn into the abdominal cavity remains speculative, but it could have either entered percutaneously or via the gastrointestinal tract (Hunt and others 2004, Stander and Kirberger 2011). Intra-abdominal granuloma or abscess formation as a result of an FB penetrating from outside the body wall has not been reported in dogs or cats. Both routes of entry by the thorn into the abdominal cavity of this wild felid were however considered. No clinical evidence of an entry port was noted on either the skin or inside of the abdominal wall or on the intestinal serosal surface. Admittedly, these surfaces were not subjected to an exhaustive search for such and entry wound, given the limitations and exigencies of the surgical procedure, which took precedence in this patient. Given the discriminate nature of feline feeding behaviour, it is interesting that this thorn could have been ingested by the cheetah, migrated through the fundic region of the stomach wall and terminated in the nephro-splenic ligament. Considering the amount of mature connective tissue formation around $\mathrm{FB}$, it is possible that the entry point, wherever it was situated, has healed completely in this time frame. Vigorous connective tissue formation associated with $\mathrm{FB}$ in this cheetah is more consistent with the response expected in cattle than domestic felidae (Braun 2009).

The lower than expected PCV in this patient was probably due to numerous haematophagus flies (Hippobosca longipennis) present in its fur.

Herein we report the successful laparoscopic removal of an FB granuloma from the abdomen of a wild captive cheetah applying SILS and an extraction bag. In wild carnivores, this surgical technique is especially useful in allowing rapid recovery and lowering the risk of postoperative surgical wound complications.

Contributors $\mathrm{MJH}$ is the main and corresponding author and acts on behalf of all authors.

\section{Competing interests None.}

Provenance and peer review Not commissioned; externally peer reviewed.

\section{REFERENCES}

ALLMAN D. A., PASTORI M. P. (2013) Duodenogastric intussusception with concurrent gastric foreign body in a dog: a case report and literature review. Journal of the American Animal Hospital Association 49, 64-69

AREF N. E. M., ABDEL-HAKIEM M. A. H. (2013) Clinical and diagnostic methods for evaluation of sharp foreign body syndrome in buffaloes. Veterinary World 6, 586-591 AWOWOLE I. O., MAKINDE O. N., TIJANI A. M., OLASEHINDE O., BADEJOKO 0. 0. (2014) Thinking beyond gauze count at surgery: a reminder to surgeons on textilomas. British Journal of Medicine and Medical Research 4, 5167-5173

BAKHTIARI J., TAVAKOLI A., KHALAJ A., GHASEMPOUR S. (2011) Minimally invasive tota splenectomy in dogs: a clinical report. International Journal of Veterinary Research 5 , 9-1275

BARANIDHARAN G. R., NAGARAJAN B., RAO G. D. J. (2013) Endoscopic diagnosis and retrieval of metallic cap in a dog. Intas Polivet 14, 123-124

BARRAULT M. J., VEDRINE B. (2013) Intravesical vegetal foreign body in a dog; corps etranger vegetal intravesical chez un chien. Point Veterinaire 44, 12-14

BATTISTI A. D., TOSCANO M. J., FORMAGGINI L. (2012) Gastric foreign body as a risk factor for gastric dilatation and volvulus in dogs. Journal of the American Veterinary Medical Association 241, 1190-1193

BECKER D. (2011) A "heart" of stone. Veterinary Technician 32, https://www.vetlearn. com/veterinary-technician/final-view-a-heart-of-stone 
BONT M. P. D., WILDERJANS H., SIMON O. (2010) Standing laparoscopic ovariectomy technique with intraabdominal dissection for removal of large pathologic ovaries in mares. Veterinary Surgery 39, 737-741

BRAUN U. (2009) Traumatic pericarditis in cattle: clinical, radiographic and ultrasonographic findings. Veterinary Journal 182, 176-186

BRENNAN S. F., CONNERY N., TOBIN E., MOONEY C. T., JONES B. R. (2004) Gastrocutaneous fistula as a result of migration of a foreign body in a dog. Journal of Small Animal Practice 45, 304-306

CHOI J. H., KIM G. D., KEH S. Y., JANG J. Y., CHOI H. Y., YOON J. (2001) Diagnostic imaging features of abdominal foreign body in dogs; retained surgical gauze. Journal of Veterinary Clinics 28, 94-100

CREEDY N., BATES N. (2011) Ingestion of multiple magnets by a dog. Veterinary Record 169,504

CULP W. T. N., ARONSON L. R. (2008) Splenic foreign body in a cat. Journal of Feline Medicine and Surgery 10, 380-383

DAY J. L., PECHMAN R. D., BAHR R. J. (2012) Migration of a retained surgical swab into the jejunum in a dog. Journal of Small Animal Practice 53, 705-708

DEBOSRI B., SONAL S. (2013) Hardware disease in cattle-a case report. Environment and Ecology 31, 401-404

DESCHAMPS J. Y., ROUX F. A. (2009) Extravesical textiloma (gossypiboma) mimicking a bladder tumor in a dog. Journal of the American Animal Hospital Association 45, 89-92

EMERSON J. A., CASE J. B., BROCK A. P., VIGANI A., GRAHAM D. R., ISAZA R. (2013) Single-incision, multicannulated, laparoscopic ovariectomy in two tigers (panthera tigris). Veterinary Quarterly 33, 108-111

HADDAD J. L., GOLDSCHMIDT M. H., PATEL R. T. (2010) Fibrosarcoma arising at the site of a retained surgical sponge in a cat. Veterinary Clinical Pathology 39, 241-246

HANRATH M., RODGERSON D. H. (2002) Laparoscopic cryptorchidectomy using electrosurgical instrumentation in standing horses. Veterinary Surgery 31, 117-124 HARTMAN M. J., MONNET E., KIRBERGER R. M., SCHMIDT-KUNTZEL A., SCHULMAN M. L., STANDER J. A., STEGMANN G. F., SCHOEMAN J. P. (2014) Laparoscopic sterilization of cheetah (Acinonyx jubatus) using single incision laparoscopic surgery. Veterinary Surgery (under review).

HOOGMOED L. M. V., GALUPPO L. D. (2005) Laparoscopic ovariectomy using the endo-GIA stapling device and endo-catch pouches and evaluation of analgesic efficacy of epidural morphine sulfate in 10 mares. Veterinary Surgery 34, 646-650

HUNT G. B., WORTH A., MARCHEVSKY A. (2004) Migration of wooden skewer foreign bodies from the gastrointestinal tract in eight dogs. Journal of Small Animal Practice 45, 362-367

KASSEM M. M., EL-KAMMAR M. H., EL-MENSHAWEY M. F. (2014) Surgical management of foreign bodies in stomach and intestine of some foreign breed dogs. Alexandria Journal of Veterinary Sciences 42, 11-15

KELLY P. A., CLOAK B., CASSIDY J. P. (2013) Unusual intravascular migration of a wooden skewer resulting in vena caval thrombosis identified postmortem in a dog. Veterinary Record Case Reports 1, e000003 doi:10.1136/vetreccr-2013-000003

KIM Y. K., PARK S. J., LEE S. Y., SUH E. H., LEE L., LEE H. C., YEON S. C. (2013) Laparoscopic nephrectomy in dogs: an initial experience of 16 experimental procedures. Veterinary Journal 198, 513-517

KUMMER M., THEISS F., JACKSON M., FURST A. (2010) Evaluation of a motorized morcellator for laparoscopic removal of granulosa-theca cell tumors in standing mares. Veterinary Surgery 39, 649-653

LARSON B. J., MADSEN L. M. (2010) Grass foreign body. Veterinary Technician 31, https://www.vetlearn.com/veterinary-technician/case-report-grass-foreign-body

LEE S. Y., SHIN B. J., JEONG S. M. (2011) Single incision flexible endoscopic cholecystectomy in dogs: feasibility study. Journal of Veterinary Clinics 28, 555-561

LUND C. M., RAGLE C. A., LUTTER J. D., FARNSWORTH K. D. (2014) Use of a motorized morcellator for elective bilateral laparoscopic ovariectomy in standing equids: 30 cases (2007-2013). Journal of the American Veterinary Medical Association 244, $1191-1197$
MAHAJAN S. K., ARUN A., VANDANA S., JITENDER M., KIRANJIT S. (2012) Surgical retrieval of a metallic foreign body from the spleen of a dog. Canadian Veterinary Journal 53, 399-401

MANASSERO M., LEPERLIER D., VALLEFUOCO R., VIATEAU V. (2012) Laparoscopic ovariectomy in dogs using a single-port multiple-access device. Veterinary Record 171,69

NAAN E. C., KIRPENSTEIJN J., DUPRE G. P., GALAC S., RADLINSKY M. G. (2013) Innovative approach to laparoscopic adrenalectomy for treatment of unilateral adrenal gland tumors in dogs. Veterinary Surgery 42, 710-715

NAIR S. S., SURESH L., NAGARAJU N., BALAPPANAVAR B. R., VASANTH M. S. (2013) Surgical management of linear intestinal foreign body in a dog. Indian Journal of Veterinary Surgery 34, 74

NAKATA M., AKIYOSHI H., YUKAWA S., HARIMAYA Y., KUWAMURA M., YAMATE J., SHIMIZU J., OHASHI F. (2012) A case of canine non-foreign-body pyogenic granuloma. Journal of the Japan Veterinary Medical Association 65, 370-373

PAPAZOGLOU L. G., TONTIS D., LOUKOPOULOS P., PATSIKAS M. N., HERMANNS W. KOUTI V., TIMOTHEOU T., LIAPIS I., TZIRIS N., RALLIS T. S. (2010) Foreign body-associated intestinal pyogranuloma resulting in intestinal obstruction in four dogs. Veterinary Record 166, 494-497

RAYNER E. L., SCUDAMORE C. L., FRANCIS I., SCHONIGER S. (2010) Abdominal fibrosarcoma associated with a retained surgical swab in a dog. Journal of Comparative Pathology 143, 81-85

RODGERSON D. H., BROWN M. P., WATT B. C., KEOUGHAN C. G., HANRATH M. (2002) Hand-assisted laparoscopic technique for removal of ovarian tumors in standing mares. Journal of the American Veterinary Medical Association 220, 1503-1507

RUNGE J. J., CURCILLO P. G. II, KING S. A., PODOLSKY E. R., HOLT D. E., DAVIDSON J., AGNELLO K. A. (2012) Initial application of reduced port surgery using the single port access technique for laparoscopic canine ovariectomy. Veterinary Surgery 41, 803-806

RUNGE J. J., MAYHEW P. D. (2013) Evaluation of single port access gastropexy and ovariectomy using articulating instruments and angled telescopes in dogs. Veterinary Surgery 42, 807-813

SHIN B. J., LEE J. Y., KIM S. H., PARK J. Y., CHOI H. J., KIM M. N., JEONG S. M. (2010) Colonoscopic diagnosis and treatment of colonic obstruction by the leaves in a dog. Journal of Veterinary Clinics 27, 113-116

SMOLEC O., HOHSTETER M., BOTTEGARO N. B., RADISIC B., PRVANOVIC N., PECIN M., KOS J. (2013) Multiple splenic abscess in cattle induced by traumatic foreign body penetration from reticulum. Conference: XIII Middle European Buiatrics Congress, Belgrade, Serbia, 5-8 June, 2013.

SPINELLA G., ROMAGNOLI N., VALENTINI S., SPADARI A. (2003) Application of the 'extraction bag' in laparoscopic treatment of unilateral and bilateral abdominal cryptorchidism in dogs. Veterinary Research Communications 27, 445-447

SPRING K. (2011) Case report: gastrointestinal perforation and omental abscessation due to magnet ingestion. Veterinary Technician 32, https://www.vetlearn.com/veterinarytechnician/case-report-gastrointestinal-perforation-and-omental-abscessation-due-tomagnet-ingestion

STANDER N., KIRBERGER R. M. (2011) Diagnostic imaging of migrating kebab (sosatie) sticks - a review of 8 cases. Journal of the South African Veterinary Association 82, 160-165

Wachter B. (2012) Personal communication. Wilson and Monnet: In: 2012 Park City, UT, p 22-24

WILSON D., MONNET E. (2012) The use of single incision laparoscopic surgery (SILS port) in dogs: description of the technique and initial impressions after 22 consecutive cases. p 22-24

WUNDERLIN N., BIEL M. PEPPLER C., AMORT K., KRAMER M. (2012) Enterocutaneous fistula formation in a dog as a result of colonic foreign body perforation. Tierarztliche Praxis.Ausgabe K, Kleintiere/Heimtiere 40, 122-128

YAKASAI I. A., ABUBAKAR I. S. (2011) Late presentation of intra-abdominal foreign body following caesarean delivery: a case report. Journal of Medicine in the Tropics $13,147-149$ 